\title{
Sight, Sound, and Surveillance in Ba'thist Syria: The Fiction of Politics in Rūzā Yāsīn Hẹan's Rough Draft and Samar Yazbik's In Her Mirrors
}

\author{
Max Weiss \\ Princeton University \\ maxweiss@princeton.edu
}

\begin{abstract}
Contemporary Syrian literature bears unmistakable traces of more than four decades of authoritarian rule. This article identifies connections among aesthetics, politics, and affect in two Syrian novels, Rūzā Yāsīn Hasan's Brūfā (Rough Draft) (2011) and Samar Yazbik's Lahā marāyā (In Her Mirrors) (2010). Through literary representations of state security (the mukhäbarät), surveillance-including the structure and function of mirrors and screens, eavesdropping, and security stations - and new conceptions of the political, state power influences cultural production, even as the contemporary Syrian novel offers a critique of authoritarian dictatorship's immanent relationship to the practice of narration itself.
\end{abstract}

\section{Keywords}

politics - Syria - Ba'thism - surveillance - mirrors - eavesdropping - affect mukhābarāt - Samar Yazbik - Rūzā Yāsīn Ḥasan - Arabic novel

Arabic literary engagements with dictatorship, the authoritarian state, and practices of surveillance can be understood in terms of historical, political, and aesthetic criteria. Lebanese poet, novelist, and critic 'Abbās Bayḍūn suggests the "mukhābarāt novel" as an analytical category for apprehending texts in which the mukhäbarāt (the state security services) play an integral part in the setting, plot, or characterization. The mukhäbarāt novel, for Baydūn, is concerned with the "stripping bare and exposure (ta'riyyah wa-kashf)" of politics in a manner that "confronts the power inside the regime (al-sultah dākhil 
al-sulțah)." Bayḍun provocatively suggests that there are at least two "heroes" in the mukhäbarāt novel, one who is "visible" - "an intellectual or a politician who has a lover or a spouse and history and roots" - and another that is either a human embodiment of the mukhābarāt or the institutions and practices of the mukhābarāt itself. ${ }^{1}$

Whereas Bayḍun suggests that this genre-if, indeed, it qualifies as onemay take the form of "a quasi-police novel," this article presents a more substantial comparative analysis of the mukhābarāt novel through a critical reading of two recent Syrian novels_-Brūfa (Rough Draft) by Rūzā Yāsīn Ḥasan, and Lahā marāya (In Her Mirrors) by Samar Yazbik. The political in early twenty-first century Syrian literature has been distinguished, at least in part, by direct and explicit engagement with the security state and its practices of surveillance and/as repression. Identifying the influence of authoritarian domination on cultural production and narrative, the Syrian mukhäbarāt novel in the first decade of the twenty-first century also suggests some of the ways in which fiction may critique, subvert, or even resist the seemingly durable and invulnerable "truth" of Ba'thist rule.

Arabic literature is littered with figures of authoritarianism. Jamāl alGhītānī's Waqā̉ichăratal-Záfarānì (The Zafarani Files) details the observations of an unnamed informant, the bașsās (the one who sees), who monitors the daily life of a popular quarter in Cairo; al-Ghițānī similarly addresses the question of political authority in his landmark al-Zaynī Barakāt (Zayni Barakat). ${ }^{2}$ The novels of Sun 'Allāh Ibrāhīm such as Tilka al-rāithah (That Smell), al-Lajnah (The Committee) and Talașșuș (Stealth) might be read under this rubric as well. ${ }^{3}$ In Ijām (Ijaam: An Iraqi Rhapsody), Sinān Anțūn outlines the conditions

1 'Abbās Bayḍūn, "Riwāyat 'al-mukhābarāt,"” Al-Safír, August 12, 2009.

2 Jamāl al-Ghițānī, Waqā̄i h hārat al-Záfarāñ̄ (Cairo: Mațba'at Madbūlī), 1976) [Gamal alGhitani, The Zafarani Files, trans. Farouk Abdel Wahab (Cairo: American University in Cairo Press, 2009)]; al-Ghīṭānī, al-Zaynī Barakāt: riwāayah (Cairo: Maktabat Madbūlī, 1975) [al-Ghitani, Zayni Barakat, trans. Farouk Abdel Wahab (Cairo: The American University in Cairo Press, 2004)].

3 Șun Allāh Ibrāhīm, Tilka al-rä̉iḩah (Cairo, 1966) [That Smell: \&, Notes From Prison, trans. Robyn Creswell (New York: New Directions, 2013)]; Ibrāhīm, al-Lajnah: riwāyah (Cairo, 1981) [The Committee: A Novel, trans. Mary S. St. Germain and Charlene Constable (Cairo: The American University in Cairo Press, 2002)]; and Ibrāhīm, al-Talașșuṣ: riwāyah (Cairo: Dār al-Mustaqbal al-'Arabī, 2007) [Stealth, trans. Hosam Aboul-Ela [New York: New Directions, 2014]). See, too, Christopher Stone, "Georg Lukács and the Improbable Realism of Șunc Allāh Ibrāhīm's The Committee," Journal of Arabic Literature Vol. 41, No. 1 (2010): 136-147. It would be instructive to also compare the ways in which affect - sight and sound and embodied experience - has been articulated in nonfiction, for example, in the case of Muștafā 
of interpretation and narration in the stultifying atmosphere of Iraq under authoritarian dictatorship. ${ }^{4}$ The protagonist in Ijjäm is a political prisoner who is bestowed the opportunity to continue writing while incarcerated, which he does, in creative camouflage, suggesting one way in which fiction, and here the novel in particular, is capable of contesting the rationality of the authoritarian state..$^{5}$ Seeing and hearing; vision and sound; communication through rumor; the stealthy accumulation of evidence or the production of truth; watching and listening; embodiment and performance-formal and thematic tropes recur throughout Arabic prose as it approaches the mukhäbarāt. Political and affective reflections of the security state, its tactics of surveillance, and techniques of rule, both in and on fiction, index the influence of state power on cultural production in Syria and elsewhere while also highlighting the potential forms of evasion, subversion, and even resistance immanent to narration itself.

A small yet vibrant and growing body of scholarship critically interrogates literature written during the three decades of Ba'th Party rule under Hāfiz alAsad (1970-2000) in Syria. ${ }^{6}$ The Syrian literary field has often been described

Khalīfah, al-Qawqa'ah:yawmiyyāt mutalașșiṣ (Beirut: Dār al-Ādāb, 2008) [The Shell: Memoirs of a Hidden Observer, trans. Paul Starkey (Northampton, MA: Interlink, 2016)].

Sinān Anțūn, Ijā̄m: riwāyah (Beirut: Dār al-Ādāb, 2004) [Sinan Antoon, Ijjaam: An Iraqi Rhapsody, trans. Sinan Antoon and Rebecca C. Johnson (San Francisco: City Lights, 2007)].

5 Friederike Pannewick, "Dancing Letters: The Art of Subversion in Sinān Anțūn's Novel Ijām," in Conflicting Narratives: War, Trauma and Memory in Iraqi Culture (Wiesbaden: Reichert Verlag, 2012), 65-74.

6 Nabīl Sulaymān and Bū 'Alī Yāsīn, al-Aydiyūlūjiỳa wa-l-adab fi Sūriyā, 1967-1973 (Beirut: Dār Ibn Khaldūn, 1974); Samar Rūhī Fayṣal, al-Ittijāh al-wāq ì fì al-riwāyah al-'arabiyyah al-sūriyyah: dirāsah (Damascus: Ittihāàd al-Kuttāb al-'Arab, 1987); Jean Fontaine, "Prose syrienne contemporaine," IBLA t. 55 n 169 (1992): 89-110; Fādiyah al-Mulayyiḥ Halawānī, al-Riwāyah wa-laydiyūlūjiya fi fi Sūriyā, 1958-199o (Damascus: al-Ahālī, 1998); Jamal Chehayed and Heidi Toelle, eds., al-Riwāyah al-sūriyyah al-mu'āșirah: al-judhūr al-thaqāfiyyah wa-l-tiqnīyāt al-riwā̄iyyah al-jadīdah: a'māl al-nadwah al-mun'aqidah fì 26 wa-27 Ayār 2000 (Dimashq: al-Ma'had alFaransī li-l-Dirāsāt al-'Arabiyyah, 2001); Mohja Kahf, "The Silences of Contemporary Syrian Literature," World Literature Today Vol. 75, No. 2 (Spring, 2001): 224-36; Elisabeth Vauthier, La création romanesque contemporaine en Syrie de 1967 à nos jours (Damascus: IFPO, 2007); R. Shareah Taleghani, "The Cocoons of Language, the Betrayals of Silence: Contemporary Syrian Prison Literature, Human Rights Discourse, and Literary Experimentalism," Ph.D. Diss., New York University, 2009; Alexa Firat, "Post-67 Discourse and the Syrian Novel: The Construction of an Autonomous Literary Field," Ph.D. Diss., University of Pennsylvania, 2010; Firat, "Cultural Battles on the Literary Field: From the Syrian Writers' Collective to the Last Days of Socialist Realism in Syria," Middle Eastern Literatures Vol. 18, No. 2 (2015): 153-176; Taleghani, "Vulnerability and Recognition in Syrian Prison Literature," International Journal of Middle East Studies Vol. 49, No. 1 (February 2017): 91-109. 
in terms of generic rigidity and ideological conformity, but it was by no means monolithic. The two novels discussed in this article, written later, challenge reductive understandings of "the totalitarian" and the sectarian in Ba 'thist Syrian society and culture. Both authors belong - in contradictory, often unresolved ways - to the 'Alawī community in Syria. An offshoot of Shīì Islam, the 'Alawī community of Syria comprises approximately ten percent of the Syrian population. Although the degree of its power, autonomy, and visibility ebbed and flowed over the course of the medieval and early modern periods, the 'Alawi community has played an outsized, and controversial, role in the political history of the country since independence in 1946, even more so since the coming to power of the Bath Party in March 1963, and especially since the November 1970 "corrective movement" (al-ḥarakah al-tașhịhiyyah) launched by Ḥāfiz alAsad. ${ }^{7}$ From the beginning of the twenty-first century, Syrian authors such as Rūzā Yāsīn Ḥasan and Samar Yazbik began to figure the authoritarian state and its methods of surveillance and repression through characters drawn from the security apparatus itself, situating the mukhābarāt-from ordinary secret agents to high-ranking officials_-alongside other figures drawn from what I shall call Syrian uncivil society. ${ }^{8}$

In 2001, critic and novelist Mohja Kahf wrote:

Contemporary Syrian literature is created in the crucible of a tenacious authoritarianism. Manifold silence, evasion, indirect figurative speech, gaps and lacunae are striking features of Syrian writing, habits of thought and wary writerly techniques have developed during an era dominated, in Syria more overwhelmingly than in other Arab countries excepting Iraq and perhaps Libya, by authoritarian governments with heavy-handed censorship policies and stringent punitive measures ... Syrian literature today is jittery with what it cannot say, and that is its genius. ${ }^{9}$

7 For a comprehensive history of the 'Alawīs in Greater Syria and Anatolia, see Stefan Winter, $A$ History of the Alawis: From Medieval Aleppo to the Turkish Republic (Princeton, N.J.: Princeton University Press, 2016). On 'Alawī doctrine and religious practice, see Yaron Friedman, The Nușayrī'Alawīs: An Introduction to the Religion, History, and Identity of the Leading Minority in Syria (Leiden: Brill, 2010).

8 The term "uncivil society" is borrowed from Stephen Kotkin and Jan Gross, who dissect and diagnose the bureaucratic and military cadres that once populated and administered the Communist regimes in Eastern Europe. Kotkin and Gross, Uncivil Society: 1989 and the Implosion of the Communist Establishment (New York: Modern Library, 2009).

9 Kahf, "The Silences of Contemporary Syrian Literature," 235. 
From as early as the 1990s, in an era of neoliberal transformation and ongoing repression-but well before the popular nonviolent uprising against the regime that broke out in early 2011-Syrian writers (and other culture producers) were experimenting with new forms of creative expression, much of which contained overtly political plots and thematic concerns. ${ }^{10}$

\section{Portrait of the Mukhābarātī as a Young Man: Rūzā Yāsīn Ḥasan's Rough Draft}

Rūzā Yāsīn Ḥasan was born in Damascus in 1974 and studied architecture at Damascus University. She published her first collection of short stories in 2000, and has published four novels since then, including Abnüs (Ebony), which won the Hanna Mina literature prize; Nighätī $f$ (Negative), what Ḥasan calls a "documentary novel" tracking the experiences of female political prisoners in Syria, including Islamists, and experimenting with multivocality as a means of narrating a collective story that muddies the boundaries between fact and fiction; and Hurrās al-haw $\bar{a}^{2}$ (Guardians of Air). ${ }^{11}$ Hasan has been a critical voice within

10 Max Weiss, "Who Laughs Last: Literary Transformations of Syrian Authoritarianism," in Middle East Authoritarianisms: Governance, Contestation, and Regime Resilience in Syria and Iran, eds. Steven Heydemann and Reinoud Leenders (Stanford, CA: Stanford University Press, 2013), 143-65. See, too, Christa Salamandra, "Prelude to an Uprising: Syrian Fictional Television and Socio-Political Critique." Jadaliyya May 17, 2012, http:// www.jadaliyya.com/pages/index/5578/prelude-to-an-uprising_syrian-fictional-television, accessed October 21, 2015; Lisa Wedeen, "Ideology and Humor in Dark Times: Notes From Syria," Critical Inquiry 39 (Summer 2013): 841-73; and, Cécile Boëx, Cinéma et politique en Syrie: écritures cinématographiques de la contestation en régime autoritaire: 1970-2010 (Paris: L'Harmattan, 2014).

11 Rūzā Yāsīn Hasan, Samā’ mulawwathah bi-l-ḍaw': qị̣aș (Beirut: Dār al-Kunūz al-Adabiyyah, 200o); Idem. Abnūs: riwāyah (Damascus: Manshūrāt Wizārat al-Thaqāfah fī alJumhūriyyah al-'Arabiyyah al-Sūriyyah, 2004); Idem. Nïghātīf min dhākirat al-mu'taqalāt al-siyāsiyyah: riwāyah tawthīqiyyah (Cairo: Markaz al-Qāhirah li-Dirāsāt Ḥuqūq alInsān, 2008); Idem. Hurrās al-hawā̉: riwāyah (Beirut: Riyāẹ el-Rayyes li-l-Kutub wa-lNashr, 2009). Very little has been written about Ḥasan. See, for example, Martina Censi, "Rappresentazioni Del Corpo Nel Romanzo Delle Scrittrici Siriane Contemporanee," Università Ca' Foscari Venezia, 2013, "Capitolo terzo: Hurrās al-hawā̄ di Rūzā Yāsīn Ḥasan: corpo e attesa o nell'attesa del corpo," 67-91; and Censi, "Rewriting the Body in the Novels of Contemporary Syrian Women Writers," in Gender and Sexuality in Muslim Cultures, ed. Gul Ozyegin (Burlington, vT: Ashgate, 2015), 297-315. In "Rewriting the Body," Censi discusses Samar Yazbik's Rāiḥat al-qirfah, Rūzā Yāsīn Ḥasan's Hurrās al-hawā̄ and Hayfā’ Bīṭār's, Imra'ah min hadhā al-'asr. Ḥasan's work has not yet been translated into English. 
the nonviolent Syrian uprising from the early days of the revolt in 2011 while she still lived in Damascus, and remains so since fleeing to Germany in 2012. In 2016, Ḥasan published her most recent novel, Al-ladhina masahahum alsihr: min shazāya al-hikāàät (Those Who Were Touched by Magic: Fragments of Stories)..$^{12}$

Her 2011 novel, Brüfā (Rough Draft), sheds light on the practice of surveillance and its relationship to politics and everyday life in Syria. ${ }^{13}$ A daydreaming secret agent with longstanding interests in literature and philosophy languishes in a lonely listening booth in a state security services station $($ far $)$ in the northwestern coastal city of Latakia. It is perhaps a consequence of his grounding in the study of philosophy that this mukhābarāti is inclined to question the ethics — and even the epistemology — of his role in the state surveillance regime. The rough draft (brüfā) of the title is his collection of notes and narratives culled from years spent in the listening booth. ${ }^{14}$ Through aural engagement with individuals he has been tasked with surveilling, the mukhābarāti attempts to spin out a rough draft of his first novel—a book subject to revision and reconceptualization throughout the text-which he envisions as trueto-life, based on actual events and feelings he is capable of accessing directly through his recorder. Rough Draft swerves from one narrative position to another, often without warning, although each chapter indicates at the outset the voice or range of voices that will be represented - third-person omniscient narration (understood to be the voice of the mukhäbarāti himself), ostensibly verbatim fragments of phone conversations, first-person diary entries by the security agent as well as his tentative reconstructions of events and even the interior thought-processes of characters. The text is also peppered with footnotes, the mukhābarāt $\vec{\imath}$ s marginalia, notes to self, and proposed revisions or embellishments. There is something unsettled and unsettling about this unfinished, perhaps even sloppy "rough draft" that has improbably made its way

12 Rūzā Yāsīn Ḥasan, al-Ladhīna masaḥahum al-sị̣r: min shazāyyā al-hikāyāt (Cologne: Dār al-Jamal, 2016).

13 Rūzā Yāsīn Ḥasan, Brūfā: riwāyahah (Beirut: Riyāḍ el-Rayyes, 2011). All translations from the Arabic are my own.

14 While the title term brüfä - an Arabic transliteration of the Italian prova - might arguably be translated as "experiment" or "rehearsal," the performative aspect of the term is less germane here than the textual and even the legalistic, in the sense of "proof" or "evidence." Hence the novel will typically be referred to by its Arabic title Brüfā, although there are points at which the textual significance of the term justifies the use of this slightly unorthodox translation, "rough draft." The "performance" of writing the rough draft—and thinking about it out loud in the narrative itself—-might merit further consideration. 
into the reader's hand as a published book..$^{15}$ These materials constitute a private, palimpsestic space that the reader winds up surveilling somehow. In this sense, the reader's perspective parallels not only the mukhābarāt $\vec{\imath}$, but also a gaze above and beyond his, one that knows things he (and presumably the reader) does not; the novel-in-progress he believes to be drafting on the sly has already been captured by a broader web of signification, namely, the recording apparatus of the regime itself, even if it gestures towards the wider world represented by the reader's subject position.

Hasan uncovers the mechanics of state control-interrogating the surveillance apparatus as a literary device - through a range of narrative strategies, including three first-person vignettes from the mukhābarāt agent himself: one at the beginning, a brief interlude in the middle, and a final bit at the novel's end. His first entry, dated Thursday, January 11, 2005, sets the scene. Sound is striking, synesthetic: the voices he hears have "a color, a mood, and an individuality;" in a turn of phrase that might be taken as ironic, he claims his sense of hearing was his "only weapon."16 If audition is a weapon, though, the mukhäbarātī does not wish to use it exclusively for patriotic purposes and in the service of the state. There is an educational and edifying potential inherent in the surveillance enterprise itself: "Sound is my gateway to knowledge and discovery, [and] since I am the one who listens, I listened, I learned and discovered." ${ }^{17}$ The mukhābarātī turns out to be more interested in capturing the everyday challenges, aspirations, and life experiences of those he repeatedly calls "my characters" than he is in carrying out orders or doing his duty to protect the homeland. "I was interested in the private lives of these people, and I recorded them for my own good, for my own interest," but he insists that their stories “would not be complete if I didn't complete them."18 The shift between first-person narration in these sections contrasts with the free indirect discourse articulated by an omniscient third-person narrator elsewhere as the indeterminacy of the mukhäbarāt $\vec{s}$ "I" comes to mirror some aspects of the disembodied surveillance and invasion of privacy conducted by the regime. ${ }^{19}$

15 In this respect, Brūfā has something in common with postmodern narrative that draws attention to the constructedness of the text, not only the draft of the mukhäbarātī here, but to the novel itself.

16 Ḥasan, Brūfā, 12.

17 Ibid., 13.

18 Ibid., 15 .

19 There is resonance here - a family resemblance, perhaps - with the Stasi agent who is the shadowy protagonist at the heart of East German writer Wolfgang Hilbig's psychological novel Ich: Wolfgang Hilbig, 'T', trans. Isabel Fargo Cole (London: Seagull Books, 2015). 
The interlude consists of a statement jotted down a few months after the mukhābarātī began his compulsory service, in which he provides a glimpse of his personal background and family life. Dated August 14, 2004, the entry announces that becoming a surveillance agent has made him feel as though he is being transformed "from an executioner into a victim." 20 One might expect that his position of relative privilege within the security services would insulate him from certain dangers associated with living under a brutal authoritarian dictatorship. He rails, however, against retrograde positions taken by his father, a man proud of his 'Alawī heritage who would go on and on about disloyalty in the country, "about the future of the sect [the 'Alawi community] if their rule were to end, about the need for our loyalty to [the sect] in order to safeguard its existence."21 There has been a great deal of scholarly and public debate concerning the extent to which the post-1970 Syrian Ba'th regime deserves to be labeled an "Alawī regime."22 It is worth recalling the apt words of Eberhard Kienle: "a monopoly by 'Alawites [of state power] is not the same thing as saying a monopoly by the 'Alawites." ${ }^{33}$ Still, the mukhäbarāt $\vec{\imath}$ s father is proud to watch his son embark upon his military service, not only as a selfidentified member of the 'Alawì community, but also he was "happy because I was going to leave behind teaching philosophy once and for all and volunteer in the mukhäbarāt." He recalls his father posing a rhetorical question to friends at a dinner party: "What do we need with philosophy and philosophizing, all the philosophers are ... traitors." Philosophy and philosophizing are unjustifiable in this vision of duty and country; his father insists that joining the mukhābarāt is "the way for him to truly serve his country, and this is how he's going to participate in protecting it from the devils who want to torch it." His father concludes, in a scoffing tone, "philosophy, he says, philosophy."24

Even as his father inveighs against perceived treason-a trope that recurs in Yazbik's Lahā marāyā (In Her Mirrors), discussed below-the mukhābarātī steals another moment of reflection, ruing the fact that he has been unfaithful by passively maintaining a sham engagement to his fiancée, Madīhah. Meanwhile, he also recognizes other infidelities, at one point analogizing the

20 Ḥasan, Brüfā, 113.

21 Ibid., 115.

22 Nikolaos van Dam, "Middle Eastern Political Clichés: 'Takriti' and 'Sunni' Rule in Iraq; 'Alawi' Rule in Syria, a Critical Appraisal," Orient Vol. 21, No. 1 (January 1980): 42-57; Fabrice Balanche, La région alaouite et le pouvoir syrien (Paris: Karthala, 2006); Balanche, "Clientélisme, communautarisme et fragmentation territoriale en Syrie," a contrario $\mathrm{N}^{\circ} 1$ (mars 2009): 122-50.

23 Eberhard Kienle, Entre jama'a et classe: le pouvoir politique en Syrie (Berlin: Das Arabische Buch, 1992), 14, emphasis added. 
treason against the homeland referenced by his father to betrayal of a more diffuse kind:

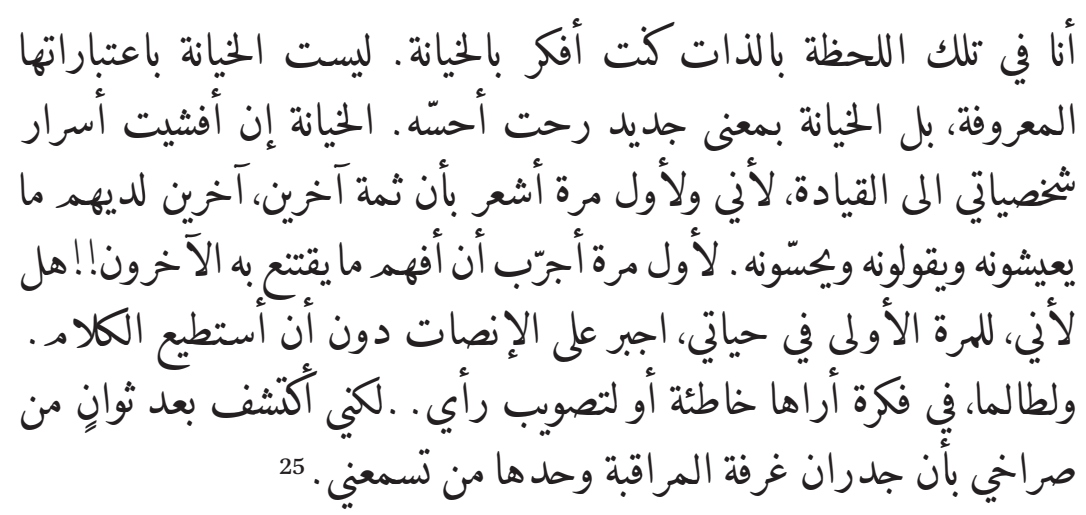

In that moment in particular I thought about treason. Not treason in its well-known meanings, but rather betrayal in another sense I had started to feel. The betrayal if I were to reveal the secrets of my characters to the authorities, because for the first time I feel as though there are others, others who have something to live for and to talk about and to feel. For the first time I try to understand what others believe!! Is that because I, for the first time in my life, was forced to listen without being able to talk? In many conversations I had always wanted to scream and cut one of them off or comment on an idea I thought was wrong or to voice my opinion or ... but after a few seconds of screaming I would discover that the walls of the monitoring room alone could hear me.

It is ironic to contemplate this experience of betrayal, even as the mukhäbarāti is betraying the confidence of "his" characters and the integrity of the security apparatus itself by sharing so much here. What would it mean, moreover, psychologically or politically, if state security agents were to believe that the transmission of "secrets" to "the authorities" constituted outright "betrayal"? Who are "the authorities" if not him? Does this imply that the mukhäbarāt and "the people" are joined through bonds of loyalty and solidarity that "the regime" threatens (and works) to undermine? Would it logically follow that the mukhäbarāti is having an affair with the state or the people? Alternatively, this passage might also be read ironically, as the mukhäbarātī tasked with being a listener for the state purports to be unaware that the reader herself-and not only the walls of the listening booth—are surveilling his listening. 
Returning to the relationship between sound and power, the mukhäbarāti asks, "What is all this that is happening to me? What is this tyranny (țughyān) that sound practices upon me?"26 The narrator imbues something as seemingly commonplace as sound with the robust authority generally associated with political tyranny. ${ }^{27}$ The contradictory experience of embodiment produced by being a subject of the regime while also serving as its agent-an unseen, notquite-all-hearing ear of the unseen, all-seeing state, as it were-disorients the mukhābarātī.

But such dysphoric anxiety encountered by the eavesdropping security agent pales in comparison with the difficult lives of "his" characters. For example, Șabā 'Abd al-Raḥmān is a young woman who has had nothing but bad luck in matters of love. After walking out on her abusive husband, bloody and battered, in May 2000 - potentially a meaningful date, one month before the death of President Haăfiz al-Asad and the succession to power by his son Bashshār - she attempts to get her life back in order even as she serially deals with men who are no good. Perhaps as a consequence of those abusive relationships, or simply because of her own liberated sexuality, Șabā engages in uninhibited amorous activity. At one point, Mihyār al-Sālimī, who is beginning to develop feelings for Șabā, invites her over for a romantic home-cooked dinner of grilled fish and vegetables. Șabā arrives bearing vodka, grapefruit juice, and a pornographic video. Mihyār is not turned on, though, and becomes mildly disoriented when she aggressively unzips his pants. ${ }^{28}$ Mihyār had been studying at the Fine Arts Academy, working part-time as a waiter in a coffee shop in order to make ends meet. He also had responsibilities taking care of his

$26 \quad$ Ibid., 113 .

27 It may not mean much that the more archaic term țughyān is used here to index tyranny rather than istibdād. One interpretation of this choice might be the attempt to distance the mukhābarātìs s conception of tyranny from the liberal critique of unjust rule, as it has been articulated and inspired by the late-nineteenth century Aleppo-born lawyer and intellectual 'Abd al-Raḥmān al-Kawākibī in his Ṭabā’i' al-istibdād wa-l-mașāri' al-isti'bād. See al-A'māl al-kāmilah li-Ád al-Raḥmān al-Kawākibī, ma'a dirāsah 'an hayātihi waathārih, ed. Muhammad 'Imārah (Cairo: al-Hay’ah al-Misrīyyah al-Āmmah li-l-Ta'līf wa-lNashr, 1970), 328-438. Alternatively, in his discussion of the political theology of Egyptian Islamist Sayyid Qutb, Ellis Goldberg notes that tughyān "has to do with overstepping boundaries (including "going beyond in disbelief")," which might go some way towards explaining the strange effects of sensory experience and individual submission to power in the case of this security agent in Brüfā. Goldberg, "Smashing Idols and the State: The Protestant Ethic and Egyptian Sunni Radicalism," Comparative Studies in Society and History Vol. 33, No. 1 (Jan., 1991), 15. 
mother, Hālah al-Sammāqī, who once worked as a secretary in a dentist's office and as a clerk in a lingerie shop before she was disabled in a freak accident. ${ }^{29}$ Mihyār is hardly a "well-adjusted" man, as we discover he is prone to using blood from his mother's used bandages in some of his paintings. ${ }^{30}$ Another character, Hānī al-'Abbās, confides in his friend al-Ayhām al-Ṣāim that he has a sexual fetish for mannequins, but only because he is unable to act upon, let alone consummate, his undying love for his sister Lamyā al-'Abbās. ${ }^{31}$

Unorthodox social behavior is not only expressed in sexual terms. The characters observed by the mukhābarātī are also fascinated by esoteric spiritual pursuits, as when Hālah al-Sammāqī puts on séances to communicate with the dead, including her husband who was assassinated — she is convinced-either by the state security forces or Islamist terrorists; she also regularly asks her son Mihyār to procure books and lectures-on-tape from the Maharishi society in India that are available in Beirut. Towards the end of the novel, after the death of his mother, Mihyār refuses to participate in a communal burial ritual, embarking instead upon a group pilgrimage to India, a "metaphysical journey" that he believes will demonstrate his "loyalty" to her and her memory. ${ }^{32}$

Through these episodic vignettes that chronicle the lives of "his" characters, the reader is invited to bear witness to the exercise of state power by a representative of the regime. Sabā moves back in with her mother in Latakia, where she manages both to recover some sense of stability as well as to reckon with what she perceives as her relative privilege:

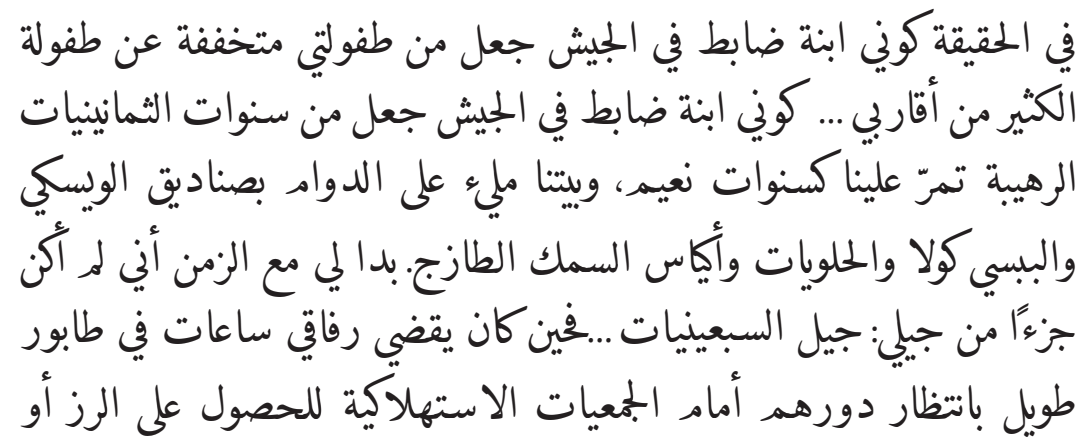

\footnotetext{
29 Ibid., 23.

$30 \quad$ Ibid., 90.

31 Ibid., 41-48, 121-129.

32 Ibid., 225-226.
} 


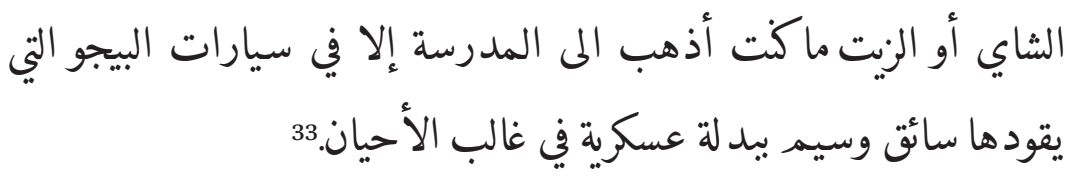

In fact, my existence as the daughter of an army officer made my childhood much easier than that of many of my peers ... my existence as a daughter of an army officer made the horrible eighties pass us by like years of felicity, and our house was constantly filled with bottles of whiskey and Pepsi Cola and sweets and sacks of fresh fish. With time it seemed to me that I wasn't a part of my generation: the generation of the seventies ... So while my friends would spend hours waiting in long lines for their turn at the consumer cooperatives in order to get rice or tea or cooking oil, I wouldn't go to school except in Peugeots driven by a handsome driver usually dressed in a military uniform.

For Șabā, her generation is damaged and deprived, suffering wide-ranging sexual and social pathologies, and subject to strictures placed upon Syrian society in the political and economic spheres under Hāfiz al-Asad. Here is a matter-offact, almost nostalgic, description of class privilege and clientelist favoritism in Ba'thist Syria. While this scathing critique of regime injustice might seem to be grounds for further investigation by an agent of the state, the mukhābarātī is more interested in how that sentiment may be a key to understanding what makes someone like Șabā (taken as a metonym for her generation) tick. The mukhābarātī relegates to a footnote the possibility of including a more detailed, "panoramic account of the Syrian political scene during the eighties, a map of alliances and struggles." ${ }^{34}$ One wonders whether the mukhābarāti has, in fact, unwittingly completed such a work of social and political mapping, albeit one that remains incomplete, in the form of his rough draft. A more comprehensive reckoning with Syria during the eighties would also have to grapple with political sectarianism. Not only did the personalized leadership of Hāfiz al-Asad secure the consolidation of Ba'thist rule through the army, the Party and the bureaucracy; the regime also engaged in intermittent civil conflict with armed as well as nonviolent opposition from leftists and Islamists, echoes of which reverberate until today. The violence of the Syrian regime during this period is nowhere better attested than by the 1982 Hama massacre, in which as many as 20,000 people perished.

33 Ibid., 38-39.

34 Ibid., 75 ff3o. 
The nature of 'Alawì belief, specifically the matter of metempsychosis or the transmigration of souls (al-taqammuș, tanāsul al-arwāh - $-\mathrm{a}$ theme that also runs through Samar Yazbik's In Her Mirrors - crops up several times. The mukhābarātī reveals his own 'Alawī background as being essential to his family's pride in the work that he does for the state, in defense of the homeland. Hālah al-Sammāqī, who suffered paralysis after a domestic accident and was left henceforth in need of constant care from her son, Mihyār, is convinced that her condition must be punishment for something she had done in a previous life. Mihyār quips that, in order to deserve such a fate, she must bear responsibility for the malevolent (re)incarnations of Hitler, Mussolini, Pinochet and Genghis Khan. Hālah laughs, but insists that he recognize, "life is much deeper than this form that is visible to us. The non-material body is the foundation."35 The vagueness of this reference notwithstanding, the sentiment seems to be reflective of an interest on the part of the mukhābarāti himself in how "his" characters discuss the relationship between appearance and essence, between illusion and reality, and the capacity to casually joke openly about 'Alawī beliefs generally not discussed in public. Beyond this reference to esoteric 'Alawī cosmology, the mukhābarātī himself operates in a conceptual universe where philosophical problems are not excluded from the discourse and experience of everyday life.

Mihyār does not put much stock in the notion that belonging to the 'Alawī community necessarily has any advantages in Syria, though. His friend alAyhām al-Ṣāim, a medical doctor trained in Libya, claims he was denied entry to a Syrian medical school because he wasn't a member of the Ba'th Party. Mihyār insists that he knows plenty of people who studied there who aren't in the Party. "Then they didn't accept me because I'm not from the ruling sect," al-Ayhām responds, using a common epithet for the 'Alawīs. Although Mihyār tries to argue back ("I know a lot of people who aren't..."), al-Ayhām interrupts him by saying, “Don't fight with me Mihyār ... they didn't accept me for some reason that has nothing to do with my ability ... of that I'm certain." ${ }^{36}$ Party membership, sectarian affiliation, and bureaucratic necessity are all grounds for corruption and exclusion.

But these larger political issues that govern "his" characters are often incidental to the mukhābarātī, obscured by his own concern with literary matters. For example, the agent expresses a kind of metafictional ambivalence, fundamentally undecided as to whether or not he ought to be a character within the text at all. In one of his place-holding footnotes, the narrator shares:

35 Ibid., 23 .

36 Ibid., 53 . 


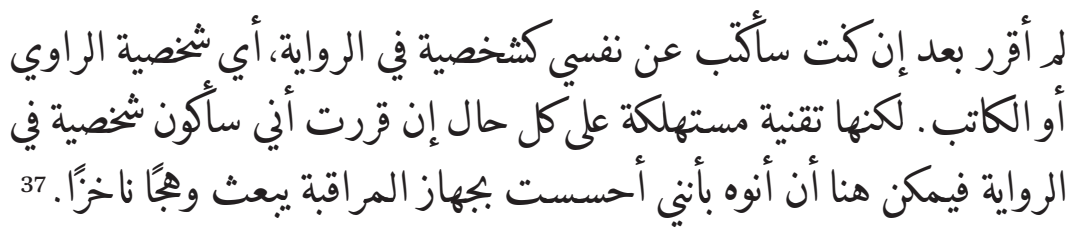

I hadn't yet decided whether I would write about myself as a character in the novel, that is, as the narrator or the writer. That's a tired technique anyway. If I do decide that I'm going to be a character in the novel, I can indicate here how I felt the listening device emitting a tingly heat.

This footnote is betrayed by the obvious inclusion of the mukhäbarāti as a character in the novel. The narrator often uses this space of the footnote in particular as a repository for his ambivalence, even as he has been a character all along.

After nearly a year spent lurking in the shadows of his characters' lives, the mukhābarāti is unable to turn up a shred of evidence demonstrating any subversive or seditious activity. There are strange moments in which the security agent notices that his subjects of surveillance are aware they are being monitored. For example, Hānī al-'Abbās, who is in love with his sister and displaces that unrequited affection onto his fetish for mannequins, appears to be approaching a breakdown. "I heard him whisper to Mihyār al-Sālimī that he felt that there was someone monitoring his phone calls," the mukhābarāti notes, but then Hānī continues his conversation, "rid of (the delusion of) his surveillance."38 Why the security agent describes this surveillance parenthetically as a "delusion" (wahm) is never explained. A clue may be found in the concluding section of the novel, though, in the mukhäbarāt $\vec{s}$ personal reflections dated Friday, January 12, 2005. “Spying on other lives isn't my life!" he exclaims. "It's a funny thing, really, for me to write: the other, the enemy, outside the circle, or whatever that can be called, it's strange for me to write down their memory in my language. As if my ear were transformed from a spying tool into a means of understanding."39 It would almost seem that the creative aims of the mukhäbarāt $\vec{s}$ surveillance, his interest in becoming a novelist, negates or at least diminishes for him understanding the act of surveillance as an invasion of privacy. Referring to his eavesdropping or his social research or his quest for literary inspiration as surveillance amounts to delusion for the mukhābarātī.

37 Ibid., 60 ff 23 .

38 Ibid., 129.

39 Ibid., 232. 
In the end, he vows not "to give a second chance to people who didn't have a second chance," and dutifully reports to his superiors because "I felt that I would betray my job if I hid any information I knew."40 But there remains a gap between the interests of the regime and the desires of this individual who helps to operate its machinery. "I wasn't interested in general activities of my characters or their political secrets," the mukhäbarātī writes. "I wasn't interested in their affiliations or their doctrinal debates or what they did against the authorities. What interested me was present and written here in my leather briefcase along with my laptop. That's all that interests me. That's all that interests me in life now."41 The narrative arc of these lives is less important than the fact that they constitute raw material for the aspiring novelist.

Ultimately, the mukhäbarāti and, by extension, the Syrian state security apparatus, much like the East German security state described by Stephen Brockman, "views writing as a method of control which will make it the lord and master of its flesh and blood characters, rather than a partner in a conversation with them." ${ }^{42}$ At the same time, though, the text is asking the reader to (re)consider the humanity of agents of the Syrian dictatorship by focusing on their ambivalent position at once inside and outside of the regime. From this vantage point, the mukhābarāti is capable of exercising a different sort of agency, one that momentarily criticizes the confining project of surveillance and asserts his ability to use the information he has amassed for his own personal purposes, to generate (real or imagined) intimate connections between the observer and the observed, the listener and the listened to, perhaps even to imaginatively disrupt the logic underwriting the security state itself, even as he would appear to be serving it.

Rūzā Yāsīn Ḥasan dedicates Brūfã to what she calls "her generation," the "generation of the seventies." Everyone caught up in the gears of the regime during this period, even those who would seem to have an enviable sinecure in the mukhäbarāt, are susceptible to sexual deviance, spiritual aimlessness, generalized anomie and psychological despair. Critics Dīmā Wannūs and Khalīl Suwaylih praise Hasan for her verve in depicting the trials and tribulations of this "disappointed generation."43 Meanwhile, Nabīl Sulaymān takes Hasan to task

\footnotetext{
$40 \quad$ Ibid., 233.

41 Ibid., 234.

42 Stephen Brockmann, Literature and German Reunification (Cambridge: Cambridge University Press, 1999), 89.

43 Dīmā Wannūs, "'Brūfāa”: riwāyat Rūzā Yāsīn Ḥasan: riwāyat al-talașșuṣ," Al-Safír, October 22, 2011 (reposted at http://alawan.org/article10568.html, accessed March 11, 2016); Khalil
} 
for concocting an implausibly omniscient narrator, ventriloquizing through the mukhābarāti in order to ruminate about highfalutin matters of intellectual concern. ${ }^{44}$ Such criticism of the Arabic novel is nothing new; Stefan G. Meyer faults the modernist experimentation of the 196os, for example, because "instead of a dialogue between distinct voices, we have merely an authorial voice in dialogue with itself." ${ }^{\prime 5}$ To be sure, Brüfā repeatedly challenges the reader as it (re)creates this character who believes only the walls are listening. It certainly may seem implausible to some that a secret agent should be so erudite and naïve at the same time. It is reasonable to question the extent to which a "reliable" or compelling narrative from the perspective of the state security services is even possible, but the humanization of the mukhäbarāt agent is one of the most striking aspects of Brūfā. The mukhäbarātī subverts state power in order to pursue dilettantish aims. At the same time, the inclusion of fragmented polyphonic narrative suggests the anomie of an often de-politicized Syrian populace scraping by under a brutal authoritarian regime. The reader is reminded that the voices of ordinary people only appear in the "transcript" produced by the mukhābarāt $\vec{s}$ s surveillance; indeed, the very conditions of possibility for narrative itself in the text are conditioned by the exercise of regime surveillance.

Rough Draft may be profitably compared to Communist and post-Communist literature and film. ${ }^{46}$ In The Lives of Others, for example, the 2006 Academy Award Winner for Best Foreign Language Film that explored the culture of listening under Stasi rule in the German Democratic Republic, a state security agent eavesdrops on bourgeois West Berliners, becoming romantically inclined towards one of them. ${ }^{47}$ The mukhäbarāt novel more generally might be read against what John Griffith Urang calls the "erotics of surveillance," in which the

Șuwayliḥ, "Rūzā Yāsīn Ḥasan: marathīyyah li-jīl al-khaybah," Al-Akhbār, July 26, 2011 (https:// www.al-akhbar.com/node/17449, accessed March 11, 2016). Nabīl Sulaymān, "Rūzā Yāsīn Ḥasan tafụaḥ lacbat al-ṣawt wa-l-tanașṣut al-istikhbārātī," AlHayāt, August 10, 2011.

45 Stefan G. Meyer, The Experimental Arabic Novel: Postcolonial Literary Modernism in the Levant (Albany: State University of New York Press, 2001), 38.

46 Volker Braun, Hinze-Kunze-Roman (Frankfurt am Main: Suhrkamp, 1985), on which see http://www.complete-review.com/reviews/braunv/hkroman.htm (accessed March 11, 2016); Christa Wolf, "What Remains," in What Remains and Other Stories trans. Heike Schwarzbauer and Rick Takvorian (New York: Farrar, Straus, and Giroux, 1993), 231-295.

47 Cheryl Dueck, "The Humanization of the Stasi in 'Das Leben der Anderen," German Studies Review Vol. 31, No. 3 (Oct., 2008): 599-6o9; John Griffith Urang, Legal Tender: Love and Legitimacy in the East German Cultural Imagination (Ithaca, N.Y.: Cornell University Press, 2010), 186-192; John T. Hamilton, “Conspiracy, Security, and Human 
security state and its apparatuses are not reducible to an impersonal or technologically-driven form of social control but diffuse into the spaces and experiences of intimate life. ${ }^{48}$ Conspiracy and conspiracy theories are turned on their heads. A "conspiratorial public sphere" under conditions of "state surveillance also creates the conditions for the 'conspiratorial' mode, that intimate confederacy of writer and reader that raises the stakes, heightens the drama, overdetermines the significance of the communication that passes between them." 49 Although Urang enjoys the benefit of hindsight, namely, literary and political perspectives from a post-Communist and re-unified Germany while the Ba'thist regime remains well in place (for the moment, anyway), this approach might throw different light on the Syrian literature of authoritarianism and the mukhābarāt novel itself.

\section{A Fractured Mirror for Prince(sse)s: Samar Yazbik's In Her Mirrors}

Samar Yazbik was born in 1970 in the northwestern Syrian coastal city of Jablah, and studied literature before working as a journalist and a screenwriter. She has published some six novels over the past decade or so. Her oeuvre has been concerned with the problem of authoritarianism in Ba'thist Syria, the politics of 'Alawī identity and community, questions of gender, and the experience of the individual in the face of state power. Yazbik represents an occasionally controversial voice in support of the Syrian revolution; her critique of the state's repression of the Syrian people, but also its manipulation of the hearts and minds of the 'Alawì community in particular, grew more pronounced as the Syrian uprising escalated and the situation descended into sectarian civil war. Her recent writings lean towards politically committed reportage on and about the Syrian war and global refugee catastrophe. ${ }^{50}$

Care in Donnersmarck's Leben Der Anderen," Historical Social Research / Historische Sozialforschung Vol. 38, No. 1 (2014): 129-41.

48 Urang, Legal Tender, esp. chapter 5, "Eye Contact: Surveillance, Perversion, and the Last Days of the GDR," 164-192. For a comparable perspective on the poetics of the Securitate in Communist Romania, see Cristina Vatulescu, Police Aesthetics: Literature, Film, and the Secret Police in Soviet Times (Stanford, Calif.: Stanford University Press, 2010).

49 Urang, Legal Tender, 171-172.

5o Samar Yazbik, Taqāṭu' nīrān: min yawmōyyāt al-intifāạah al-sūriyyah (Beirut: Dār al-Ādāb, 2012) [Samar Yazbek, A Woman in the Crossfire: Diaries of the Syrian Revolution, trans. Max Weiss (London: Haus Publishing, 2012).]; Idem., Bawwābāt ard al-'adam (Beirut: Dār alĀdāb, 2015) [Samar Yazbek, The Crossing: My Journey to the Shattered Heart of Syria, trans. Nashwa Gowanlock and Ruth Ahmedzai Kemp (London: Rider Books, 2015).]. 
If $B r u \bar{u} f \bar{a}$ directly engages with the politics and poetics of domestic espionage, occasionally wrestling with the relationship between the 'Alawi community and the Syrian Bathist regime, Samar Yazbik brings to bear a rather more severe condemnation of the mukhäbarāt state and its intimate forms of surveillance by way of a romantic re-enactment of 'Alawī history and memory. ${ }^{51}$ Lahā marāya (In Her Mirrors) (2010) is a tragic romance, which continues to track themes-Alawī identity, patriarchy, friendship, political corruptionthat were central to her previous novel Șalșăl (Clay) (2005). Lahà marāya is the tale of Laylā al-Ṣāwī, a washed-up television and film star, and her tormented love affair with Sa'ìd Nāșir, a fellow 'Alawī who hails from the same village and is a high-ranking military figure with personal connections to the ruling elite. Despite the fact that her family and community have been trampled by the regime he defends, Laylā is unable to overcome her attraction to Saīd Nāșir. Their tortured love story is a kind of fractured 'Alawi fairy tale set against the backdrop of history, in which the tragic connection linking these two "soul mates" survives the transmigration of their souls. ${ }^{52}$

Lahā marāy $\bar{a}$ opens with the death of the President, placing the reader squarely in Syria in the year 2000. Having just heard the breaking news, Sa'id Nāșir watches the funeral on national television from his mountain retreat in the coastal northwest. He is disgusted to see the president's body borne along by an ordinary cart rather than held aloft on the people's shoulders, as that was "how the president came out, from the people, and that's how he should return!"; 53 wracked with guilt for not being there in order to arrange "a funeral adequate to the majesty of the leader, the leader who will never die." ${ }^{n 4}$ In addition to a fulsome statement of obsequiousness before the president's legacy, here, too, is an allusion to the "eternal leader" (al-qāid ilā al-abad), a standard reference to President Hafiz al-Asad in state and Party discourse. The phrase owes something to the intellectual genealogy of Bathism itself, which turns on the motto, "a single Arab nation with an everlasting message" (ummah 'arabiyyah wāhidah dhāt risālah khälidah). Still in shock over the president's

$5^{1}$ Samar Yazbik: Mufradāt imrā̉ah: qișaș (Beirut: Dār al-Kunūz al-Adabiyyah, 2001); Idem. Tiflat al-samā’: riwāyah (Beirut: Dār al-Kunūz al-Adabīyyah, 2002); Idem. Șalṣāl: riwāyah (Beirut: Dār al-Kunūz al-Adabiyyah, 2005); Idem. Jabal al-zanābiq: ḩaky manāmāt (Damascus: Dār al-Madā li-l-Thaqāfah wa-l-Nashr, 2008); Idem. Rā̇ị̂at al-qirfah: riwāayah (Beirut: Dār al-Ādāb, 2008).

52 Samar Yazbik, Lahā marāyā: riwāyah (Beirut: Dār al-Ādāb, 2010). Subsequent references to the novel appear in the text; all translations from the Arabic are my own.

53 Ibid., 13 .

54 Ibid., 67. 
demise, Sa'îd Nāșir reminisces about formative political experiences he and the leader shared during their tumultuous adolescence, buffeted by coups and military instability. He recalls having told the future president in a discussion about political responsibility, "Security doesn't mean force alone, it means making the people trust in you and entrust themselves to you." The president responded, "The Party needs intelligent and devoted people like you,"55 an expression that will come to haunt Laylā and her family later on.

Laylā served jail time for political dissidence. On the inside, she degenerated into an addict hooked on heroin and hashish. Although disheveled and disoriented upon her release, Laylā is now dead set on piecing together her shattered life. Arriving on the doorstep of the House of Beauty, her salon and long-time hangout in the city, she ruminates on how different it is to be clean than to be using. When she was high, her "magic needle" would transform her into "a princess, or an invisible creature, a transparent creature, unseen, unseeing." ${ }^{\prime 6}$ If the aural dimensions of surveillance are central to Brūfā, Lahā marāyā highlights the political and personal power associated with vision and ways of seeing. As Laylā stumbles across the threshold of the salon, her old confidante and stylist Mārī tells her "the world is turned upside down outside. The president is dead. ${ }^{\prime 57}$ Mārī was the only one to visit her in prison—until Sa'īd Nāṣir personally forbade her from receiving any visitors at all—and Laylā shared stories of having her head shaved while incarcerated, of nonstop degradation and abuse, of being gang-raped. ${ }^{58}$ With nowhere else to turn, Laylā crashes with Mārī, who still lives with her abusive mother. Laylā confides in Mārī how her mind constantly returns to Sa'īd Nāșir even as she rebukes herself for wanting to see him again after he left her to rot in prison for so long.

The backstory of Laylā's family is stitched into the tapestry of 'Alawī sacred and secular history. She is the granddaughter of a notable 'Alawi figure from the northwest, Shaykh 'Alī al-Ṣāwī, whose family fled persecution in order to settle in a mud house on the outskirts of their village until his son moved to the capital and saved up enough money to build a nicer house up on an adjacent mountain. Sa'ìd Nāșir's family and others derided Shaykh 'Alī, describing him as a kook who was only concerned with preserving his collection of books, a special box he imbued with magical properties, and some yellowing papersthe physical inheritance of the community. Shaykh 'Ali fought against the French colonial forces, participating in one of the locally organized rebellions

\footnotetext{
$55 \quad$ Ibid., 163.

56 Ibid., 24 .

57 Ibid., 26.

$5^{8}$ Ibid., 29-33.
} 
that broke out against foreign intervention in the aftermath of the First World War. Historians debate the significance and symbolism of the Shaykh Șālih al'Alī revolt in terms of the relationship between 'Alawī particularism and Syrian nationalism, but mention is often made of him in order to gesture towards his anti-colonial nationalist credentials, which is precisely what is at stake in this struggle over family history and memory. 59

The history and memory of both Ottoman and French persecution of the 'Alawī community remain important to Laylā and her family, but neither one overshadows the political repression suffered by Syrians of all sectarian affiliations in the authoritarian present of the novel. Laylā's younger brother 'Alī, a medical student, is sent to jail for dissident political activity. When Laylā discovers that 'Alī had been detained and tortured—and that it was none other than Saīd Nāșir who authorized his arrest—she is devastated. The story of 'Ali's interrogation - narrated in a flashback from the perspective of Sa'ìd Nāșir, who was not only present but supervised the proceedings-brings to the fore the politics of identity and community under Bathist authoritarian dictatorship. At first Saīi Nāșir offers kind words about his family but then condemns him for consorting with scum (ḥuthālah):

59 The character, Shaykh 'Alī, is described as having been a contemporary of Shaykh Șālih al-Alī, an 'Alawī leader who organized an uprising that acquired mythical status in 'Alawī collective memory but also has had a complicated relationship with Syrian nationalist historiography. On the history, historiography, and memory of the Shaykh Șaaliḥ al-'Alī revolt, see 'Abd al-Lațîf al-Yūnus, Thawrat al-Shaykh Șālị̣ al-Alī ([Damascus]: Dār al-Yaqẓah al-'Arabiyyah, 1961 [1947]); Ḥāmid Ḥasan, Șālị̣ al-'Alī thā̉iran wa-shā'iran (Damascus: Manshūrāt Dār Majallāt al-Thaqāfah, 1973); Ayman Aḥmad Sha'bān, Șālị̣ al'Alì thawrah wa-'aqìdah (Damascus: A.A. Sha'bān, 1989); Joshua M. Landis, "Nationalism and the Politics of Za'ama: The Collapse of Republican Syria, 1945-1949," Ph.D. Diss., Princeton University, 1997, 113, 150-158; Qays Ibrāhīm 'Abbās, al-Shaykh Ṣăliḥ al-Alī: awrāq wa-shahādāt (Damascus: al-Takwīn, 2005); 'Isā Abū 'Allūsh, Șafahāt majhūlah min thawrat al-Shaykh Șālị̣ al-'Alī (Latakia: Dār Dhū al-Fiqār li-l-Ṭibā'ah wa-l-Nashr wa-l-Tawzī', 2007); Mạ̣mūd 'Abd al-Raḥmān Āl 'Abbās Salmān, Imām al-mujāhidīn wa-shaykh althuwwār al-Shaykh Șāliḥ al-Alī: qā̉id wa-qadiyyah (Tartus: Maktabat Shāsh, 2009); Winter, A History of the 'Alawis, 244-256. On French discursive constructions of the 'Alawī community more generally under the Mandate, and after, see Max Weiss, "Community, Sect, Nation: Colonial and Social Scientific Discourses on the 'Alawīs in Syria during the French Mandate and Early Independence Periods," in The Alawis of Syria: War, Faith and Politics in the Levant, eds. Michael Kerr and Craig Larkin (New York: Oxford University Press, 2015), 63-75. 


$$
\begin{aligned}
& \text { ـ قل يا عليّ؛ كيف اجتمعت بهولاء الحثنالة وصرت واحدًا منهم ؟ }
\end{aligned}
$$

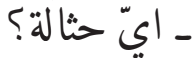

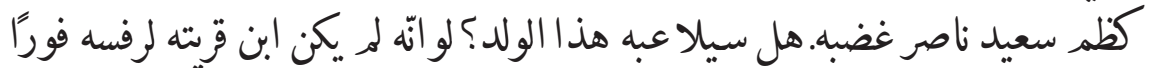

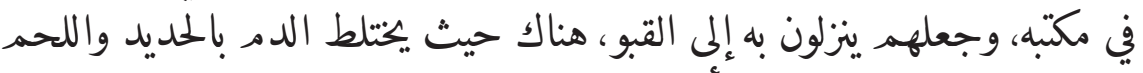

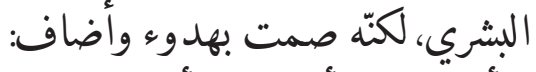

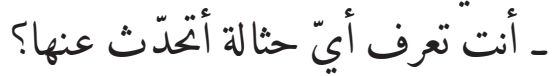

$$
\begin{aligned}
& \text { ـ لم يعد هناك من حثالة. }
\end{aligned}
$$

"Tell me, 'Alī, how did you meet those scum and become one of them?" "Which scum?"

Sa ${ }^{c} 1$ id Nāșir suppressed his rage. Was this little boy playing with him? Were they not children of the same village, he would have stomped him right then and there in his office, made them take him down to the cellar, where blood and iron and human flesh are mixed together, but he remained calmly silent, then added:

"You know which scum I'm talking about."

"Nobody is scum anymore."

Despite his vulnerability to Sa'īd Nāșir's unchecked power, 'Alī does not back down.

$$
\begin{aligned}
& \text { ـصحيح لم يبق هناك من حثالة، ولن نسمح بأن تكون هناك حثالة ... أنت } \\
& \text { توافقني أنّهم حثالة }
\end{aligned}
$$

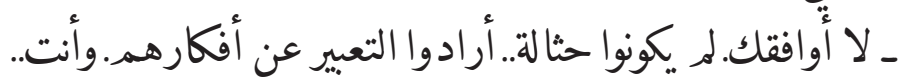

$$
\begin{aligned}
& \text { قاطعه بلهجة حاسمة وغاضبة: }
\end{aligned}
$$

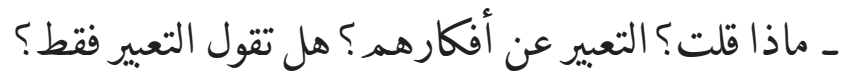

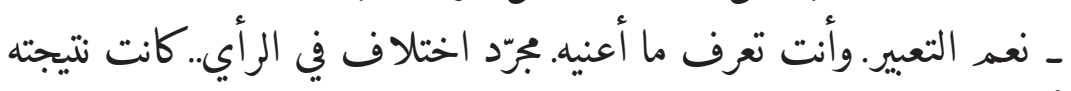

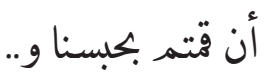




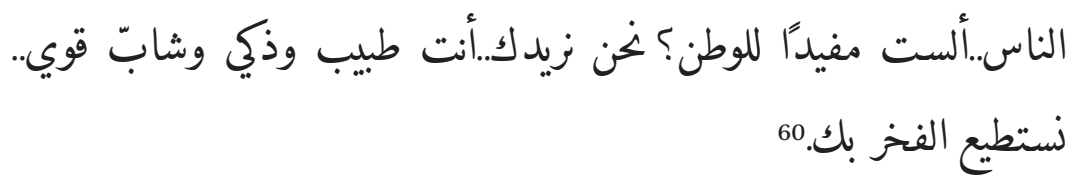

"You're right. There are no scum left, and we won't allow there to be any more scum ... Don't you agree with me that they're scum, though?" "I don't. They weren't scum. They just wanted to express their ideas. And you..."

He cut him off with a sharp and angry tone:

"What did you say? To express their ideas? Just expression, you say?!"

"That's right, just expression. And you know what I mean. Just a difference of opinion. And because of that you lock all of us up and..."

"Great. Just great. Now you're speaking in the plural, which means that you're ... anyway, that's not the point. The important thing is that it pains me to see the grandson of Shaykh al-Șāwī among those people. Are you of any use for the homeland? We want you ... you're a doctor, intelligent, a strong young man ... we could be proud of you."

Sa'īd Nāṣir echoes the intimate language the President once used with him, expresses concern for 'Alī, his life, his reputation and that of his family through his use of what we might call, following Urang, the "conspiratorial" mode, how language and communication function in the intimate spaces of surveillance and repression. ${ }^{61}$ The conspiratorial tone of narration mirrors but also potentially subverts the demands of loyalty, solidarity, and identification with the Leader and his power. At times cajoling, at times heartfelt, Sa ${ }^{\top} \mathrm{i} d$ Nāșir insists that involvement in an opposition party can only come to a bad end:

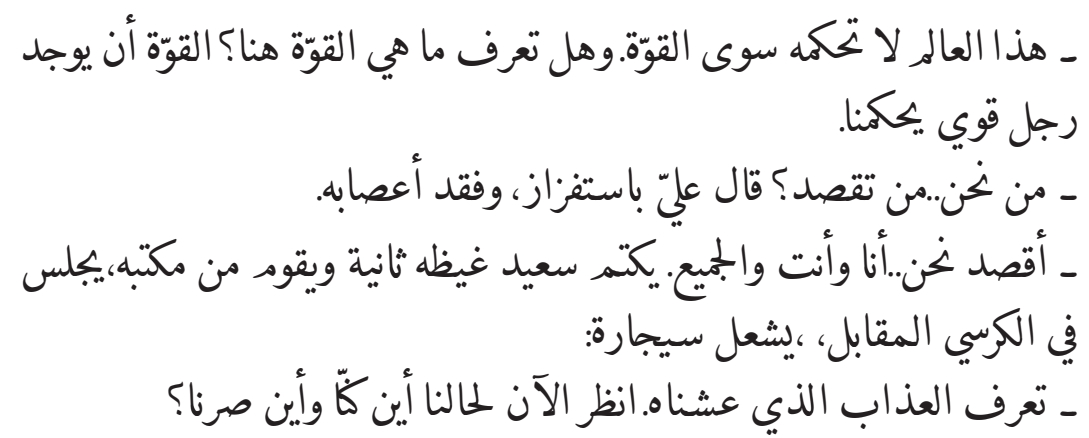

6o Yazbik, Lahā marāyā, 148-149.

61 Urang, Legal Tender, 171-172. 
"This world is ruled by power alone. And do you know what power is here? Power is for there to be a strong man who rules us."

"What do you mean by 'us' ... who do you mean?" 'Alì replied provocatively, having lost his nerve.

"I mean us ... me and you and everyone else." Saīd Nāșir conceals his rage again, gets up from his desk and sits down on a chair on the other side of the room, lighting up a cigarette. "Do you know what kind of torture we went through? Take a good look now at our situation, where we once were, how far we've come."

Despite this invocation of power and force, 'Alī remains defiant:

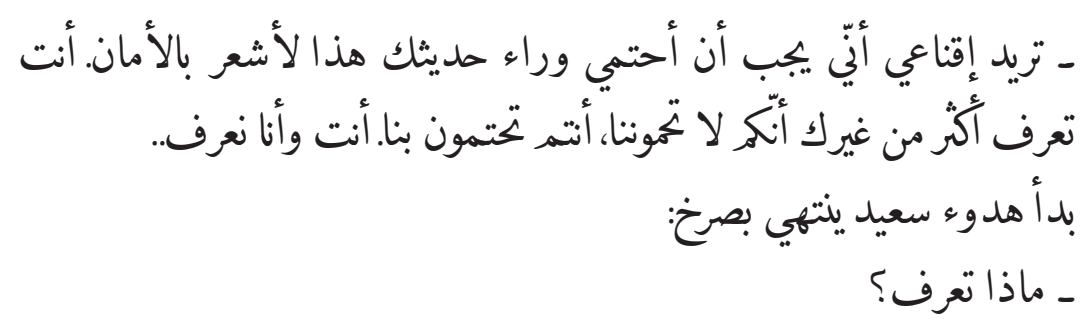

"You think you can convince me that I have to take shelter behind this slogan of yours in order to feel secure? You know better than most that you don't protect us: you're protected by us. You and I both know that..." Sa'îd's calmness began to subside, and he shouted, "What the hell do you know?!"62

At this point, the reader enters 'Ali's thoughts through free indirect discourse. This shift towards third-person omniscient narration might be said to mirror 'Alì's vulnerability and victimization, literally taking away his capacity to narrate the ongoing scene. Even if he would admit that he and his friends might have been idealistic, 'Alī refuses to let anyone question his integrity by calling him a traitor:

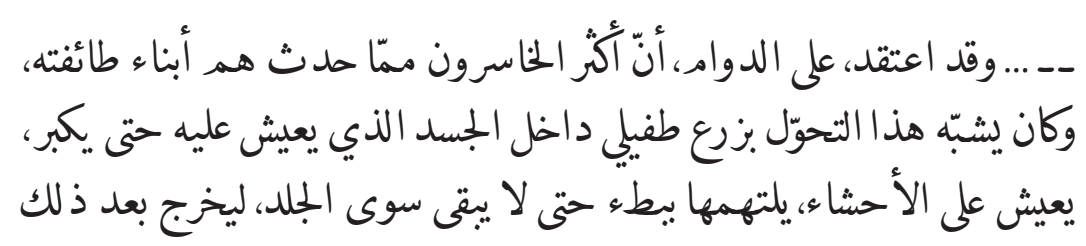

62 Yazbik, Lahā marāyā, 150 . 


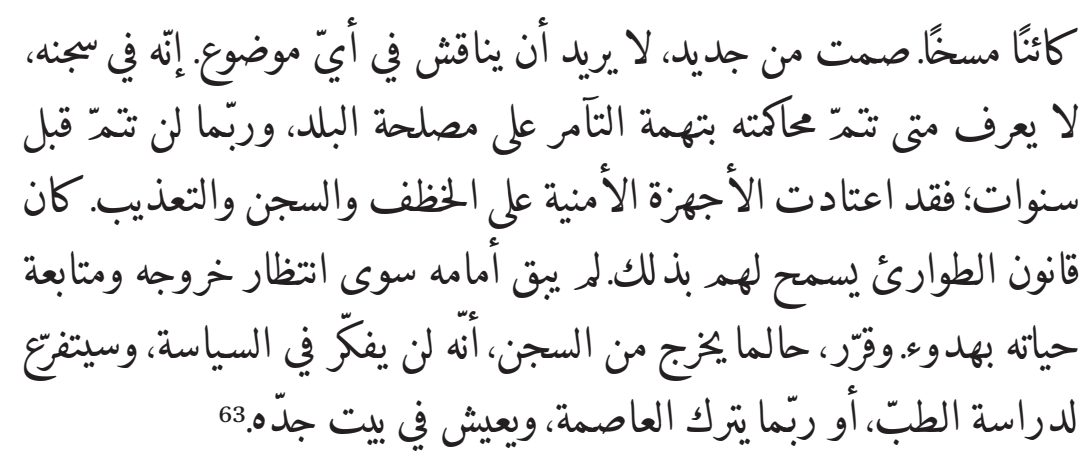

He always believed that the biggest losers in all that was happening were the people of his sect, which he likened to a parasite burrowing inside his body, dwelling inside his stomach, devouring slowly until nothing but skin remained, to emerge later on as a monstrous creature. He was silent once again. He didn't want to discuss anything. He was in his prison, not knowing when he would be tried for the crime of conspiracy against the public good of the country, perhaps it wouldn't be for years. The security apparatus had long been accustomed to kidnapping and imprisonment and torture. The emergency law allowed them to do that. All he could do was await his release and [hope to] peacefully get on with his life. He decided that, as soon as he got out, he wouldn't ever think about politics; he would re-dedicate himself to studying medicine, or maybe he would leave the capital altogether and go live in his grandfather's house.

Briefly emerging from this reverie, 'Alì feebly attempts to defend himself, but Saīd Nāṣir interrupts, scoffing at his weakness even as he confesses how this display of willfulness reminds him of his own youth, when he and his peers were persecuted, "imprisoned and tortured" for their subversive activities. 'Alì continues in defense of himself and his comrades:

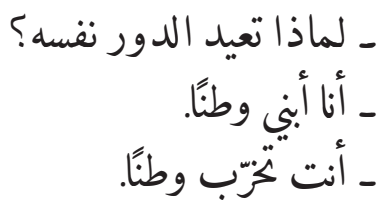

"So why are you doing the same thing to us?"

"I'm building a homeland."

"You're destroying one."64

$\begin{array}{ll}63 & \text { Ibid., } 15^{-1} 5^{2} . \\ 64 & \text { Ibid., } 153 .\end{array}$ 
"The traitor," as Tobias Kelly and Sharika Thiranagama argue, "lies not so much at the margins or beyond the nation but at its heart." ${ }^{65}$ Saīd Nāṣir smacks 'Alī to the ground and proceeds to beat him further, insulting him all the while, ${ }^{66}$ but 'Alī will not submit:

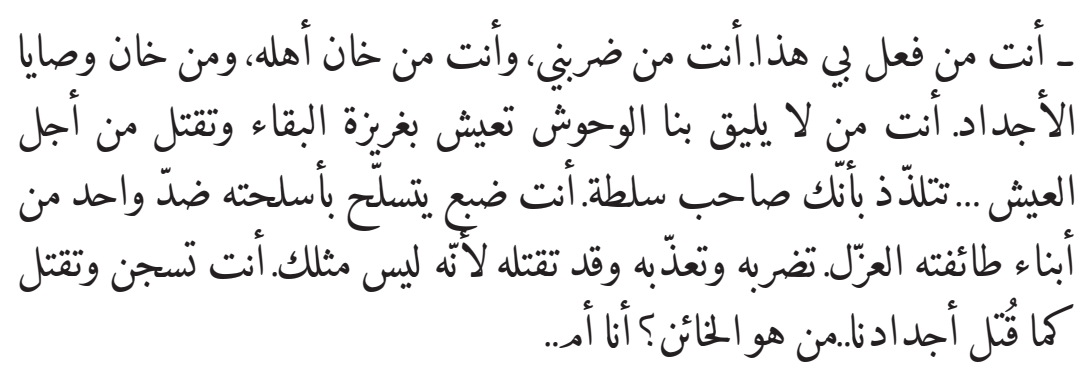

"You're the one who did this, you're the one beating me, and you're the one who's a traitor to his people, a traitor to the legacy of our ancestors. You're the one who doesn't belong. Wild animals live by the survival instinct and kill in order to live ... You take pleasure in the fact that you have all the power. You're a jackal arming himself in order to use his weapons on someone from his own sect who is defenseless. You beat him and torture him and you might even kill him just because he isn't like you. You jail and kill people the way it was done to our ancestors ... Who's the traitor? Is it me or is it ..."

Sacīd Nāșir flicks away his cigarette, unhinged, leaping up to pulverize 'Alī, smashing his head against the wall, stomping on him, pounding him with a chair, until his colleagues have to step in and restrain him. 'Alī winds up in a coma that lasts for days, and won't remember what happened, not just that day, but many others as well, suffering from localized amnesia. ${ }^{67}$

After his release, Laylā tries to persuade 'Alī to abandon his political activities. 'Alī, in turn, tries to convince her to move back to the village with him, to get away from Sa'īd Nāṣir. He is shocked to discover that Sa'īd Nāṣir has "bought her a big house, broke all her mirrors, and prevented her from having mirrors in her new house." 68 When 'Alī asks if she's happy, she says she doesn't know:

65 Sharika Thiranagama and Tobias Kelly, "Introduction: Specters of Treason," in Traitors: Suspicion, Intimacy, and the Ethics of State-Building, eds. Thiranagama and Kelly (Philadelphia: University of Pennsylvania Press, 2010), 9.

66 Yazbik, Lahā marāyā, 154.

67 Ibid., 155 .

68 Ibid., 203. 


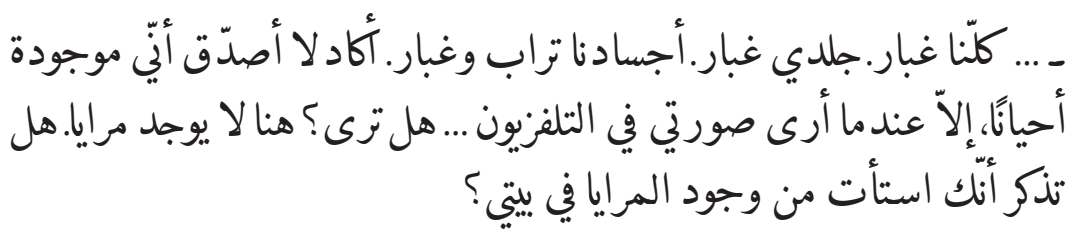

"We're all just dust. My skin is dust. Our bodies are earth and dust. Sometimes I almost don't believe I even exist, except when I see myself on television ... Don't you see? There are no mirrors here. Do you remember how you used to disapprove of all the mirrors in my home?"

Slowly realizing that some part of Laylā has been destroyed, that TV has become her psychological screen, that her connection to reality is growing increasingly tenuous, 'Alī probes further, inquiring about her mirrors. Laylā responds:

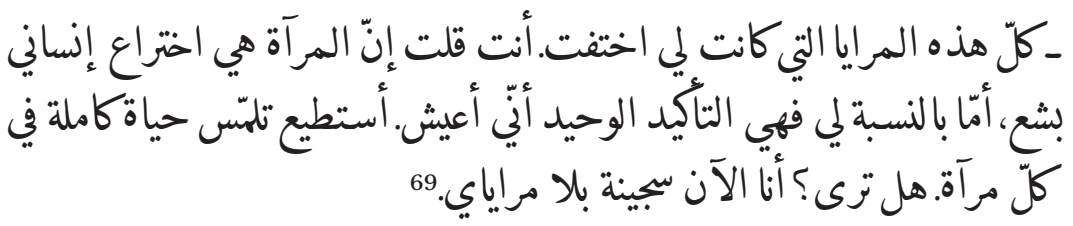

"All those mirrors I once had have disappeared. You once said that the mirror is a hideous human invention, but for me it's the only certainty I have that I am alive. I can feel an entire life in every mirror. Don't you see? Now I'm a prisoner without my mirrors."

Laylā seems to be articulating a philosophy of life, perhaps even an ontology: "mirrors are the opposite of what people say about them being the love of the self! They're a place of nothingness ... a place for you and you alone ... where there's nothing but the void."70 'Alī unsuccessfully pleads with her to return to the village: "Come back with me, Laylā ... or [at least] go back to your mirrors."71 In the end, 'Alī goes home alone.

The confusion of living in such a kaleidoscopic reality, of striving to see through propaganda, intimate disinformation, and political paranoia, is epitomized by Laylā's obsession with mirrors. Laylā seems to be stranded in "the mirror stage," the notion popularized by French psychoanalyst Jacques Lacan (1901-1981), in which the developing human subject is alienated from himself or herself, but which should also function as a transitional step to-

$\begin{array}{ll}69 & \text { Ibid., } 206 . \\ 70 & \text { Ibid., 207. } \\ 71 & \text { Ibid., 209. }\end{array}$


wards self-identification, even if that subject-formation is only ever partial or incomplete. ${ }^{72}$ Michel Foucault took those insights further in "Des espaces autres," viewing the mirror as a space both from and toward which a radical politics of presence — one marked on and by the body — may be enacted. ${ }^{73}$ Space and the body may be rendered "utopian," but Foucault also suggests that this utopian body (le corps utopique) may turn out not to be a utopia at all. For Foucault, "utopias are non-fictional, even though they are also non-existent. Utopias in fact come to us as barely audible messages from a future that may never come into being." ${ }^{.74}$ As long as the non-identical self appears in the mirror before the developing subject, Foucault notes that there are other spaces, forms of alterity, alternate universes — not all of which are imaginary-toward which the human subject may strive or be inclined: "hetero-topias, those spaces that are absolutely other." ${ }^{\prime 5}$ But heterotopia has its flip side: bodies on this side of the looking glass that are fragile, docile, and, perhaps most importantly, subject to various kinds of power.

Syria under Ba'thist rule might be thought of as a house of mirrors. Keywords such as "liberty, "unity," and "socialism" as well as "women's liberation" and "equality" were evacuated of content and ideologically repurposed in the service of state power. Before her psychological unraveling, Laylā slept in a room that had mirrors hanging from the walls and the ceiling: "When she would lay down on her bed, turning on the small lamp beside it, and looking up into the mirror, she would look like a distant point approaching from an infinite darkness. She would close her eyes and feel safe, as if the reflections spreading all

72 Jacques Lacan, "The Mirror Stage as Formative of the Function of the I as Revealed in Psychoanalytic Experience," in Écrits: A Selection, trans. Alan Sheridan (New York: Norton, 1977), 6. On the development of Lacan's thinking about the mirror stage as well as his often-overlooked debt to the French psychologist Henri Wallon (1879-1962), see Jane Gallop, "Lacan's 'Mirror State': Where to Begin," SubStance: A Review of Theory and Literary Criticism 37/38 (1983): 118-28; Martin Jay, Downcast Eyes: The Denigration of Vision in Twentieth-Century French Thought (Berkeley: University of California Press, 1993), 339-352; Elisabeth Roudinesco, "The Mirror Stage: An Obliterated Archive," trans. Barbara Bray, in The Cambridge Companion to Lacan ed. Jean-Michel Rabaté (Cambridge: Cambridge University Press, 2003), 25-34.

73 Michel Foucault, Dits et écrits 1984, "Des espaces autres" (Conférence au Cercle d'études architecturales, 14 mars 1967)," in Architecture, Mouvement, Continuité, $\mathrm{n}^{\circ} 5$ (octobre 1984): 46-49; all references are to the expanded and "corrected" text published in Foucault, $\mathrm{Le}$ corps utopique: suivi de les hétérotopies (Paris: Lignes, 2009). The translations are my own.

74 Jameson, "The Politics of Utopia," New Left Review 25 (Jan/Feb 2004), 54 (35-54).

75 Foucault, Le corps utopique, 25. 
around her were the realization of her very existence."76 In contrast to clinical conceptions of narcissism as an obsession with the self by way of a fixation on the mirror (or reflecting pool, in the classical version), Laylā insists that selfregard in her own mirrors is a means of annihilating the self. Mirrors function here, somewhat counter-intuitively, to anchor Laylā in the reality of her circumstances in authoritarian Syria, to establish the very conditions of possibility for her experience of being. 'Alī once described politics and his sister as his only connections to the world. There was a "strong rope" tethering him to life, with Laylā representing a "knot of the rope."77 The rope metaphor comes back to shock Laylā after 'Alī moves back to the village, where he becomes increasingly despondent and eventually hangs himself inside the family's old mud house.

If Lahā marāya proceeded in a minor key up until this point, the conclusion swells to a dooming crescendo. Laylā plummets into a drug-fueled madness as her grip on reality slips. She has, as she puts it, "lost her mirrors," ${ }^{18}$ lost her marbles, her bearings. Unmoored from the country she (thought she) once knew, Laylā no longer has access to the space of retreat embodied by her mirrors either. She forgets whatever dreams she had of reviving her acting career: "She forgot everything, thinking how she wanted to write an end to the story between her and Saīd Nāșir so that 'Alī's soul could be at peace."79 This deeper disruption of her dysphoria sends her hurtling towards collapse.

Meanwhile, Sa'îd Nāṣir loses patience with Laylā, telling her that the mourning period (hidād) following 'Alì's suicide has passed. ${ }^{80}$ Still she persists in demanding to know what happened to him:

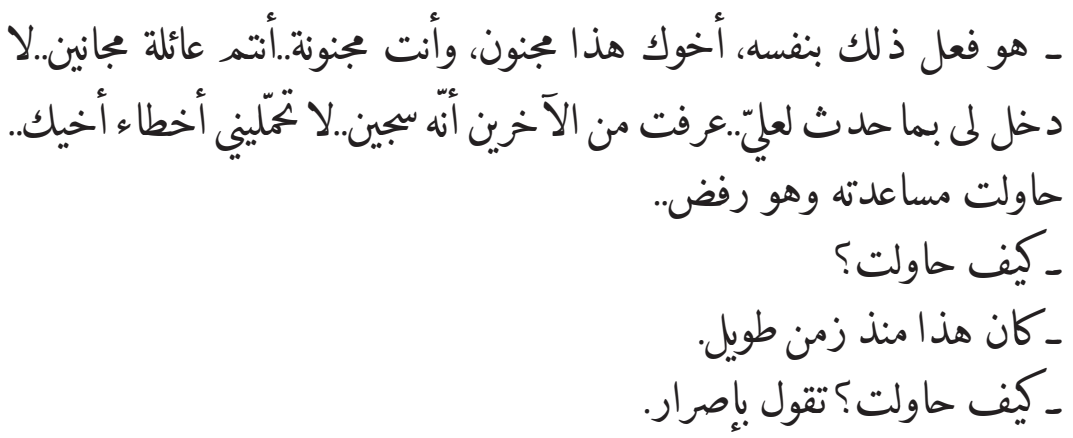

76 Yazbik, Lahā marāyā, 119-120.

77 Ibid., 117 .

78 Ibid., 241.

79 Ibid., 244.

$80 \quad$ Ibid., 251. 


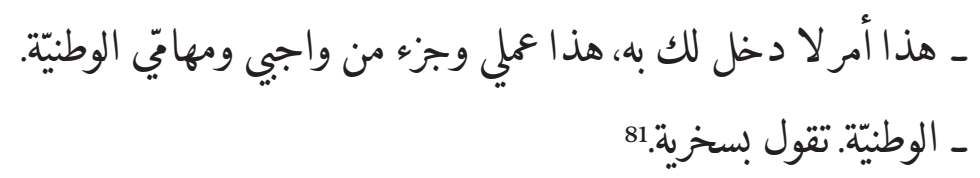

"He brought it upon himself. That brother of yours was crazy, and so are you ... Your family is a bunch of crazies ... I didn't have anything to do with what happened to 'Alī ... I heard from others that he was in jail ... don't blame me for your brother's mistakes ... I tried to help him but he refused..."

"How did you try?"

"That was a long time ago."

"How did you try?" she insisted.

"None of your business. It's my job, part of my patriotic duty and responsibilities."

"Patriotic," she said sarcastically.

Whereas the mukhābarātī in Brūfā did not seem to do his "patriotic duty" with a great deal of conviction, Sa'̄ì Nāșir is a true believer in national loyalty, and he doesn't hesitate to mete out cruelty against dissidents and intimates alike. Desperate and distraught, Laylā momentarily attacks Saīì Nāṣir before collapsing into a crumpled heap.

Laylā relapses into addiction, careening out of control. In a way that might be read as complementing Laylā's fractured psyche, the temporality of the novel splits open as successive sections trace the relationship between Laylā and Sa'̄ì Nāṣir as a story of star-crossed lovers that spans centuries of Greater Syrian and Anatolian history. In the description of their ancestral village, to which 'Alawīs had fled from massacres and persecution, the people were said to have had to "carry their souls in their hands" (yaḥmilūn arwāhahum 'alā akuffinim). ${ }^{82}$ This idiomatic expression carries at least two meanings. First, historically speaking, 'Alawīs who were chased from their homes had to take their lives into their own hands. At the same time, when sacred texts were burned and as esoteric beliefs and ritual practices had to be hidden behind the practice of taqiyah (purposeful dissimulation), the community was steadily denuded of its cultural memory. Wonders once taken for truth were transformed over time into "ancient tales" (hikāyāt müghilah fı al-qidam) as the "survivors" of the community turned 'Alawì sacred history into "superstitions and myths" that were subsequently forgotten along with the "souls" (arwāh) that were lost

\footnotetext{
81 Ibid., $25^{2-253}$.

82 Ibid., 39 .
} 
in those massacres. ${ }^{83}$ As Sa'ìd Nāṣir plies Laylā with hashish and opiates, 'Alawī belief in reincarnation - metempsychosis or the transmigration of souls-becomes crucial. She insists that the two of them had been lovers "for generations," convinced they knew one another in past lives, one of which ended in the early-sixteenth century with the two of them dying in each other's arms as Ottoman Sultan Selim I conquered Aleppo. The persecution of the 'Alawi community in what is referred to as "the white city" (al-madinah al-bayd $\bar{a}$ ) in the novel (as opposed to its more traditional moniker, "Aleppo the gray" [Halab alshahb $\left.\bar{a}^{3}\right]$ ), is reconstructed in gory detail. ${ }^{84}$ These sections fudge the boundaries between history and myth..$^{85}$ Should these stories be taken as "real," a lived aspect of 'Alawī cosmogony in which the transmigration of souls is a social reality? Has Laylā gone mad- "lost her mirrors" - in the wake of her traumatic prison experiences? Did her brother's suicide cause her to snap? Was Sa'id Nāșir's emotional abuse taking its toll? Or had drug use irrevocably twisted her mind, propelling her into a phantasmagorical dream world? If the novel provokes such stimulating questions, the reader is ultimately confronted with its overdetermined undecidability.

Wasting away in a spare garret in the Shalān neighborhood, adrift in her chemically addled state, Laylā is broken. Mirroring her grief over 'Alī's tragic demise, words have become "like a noose hanging in [her] throat." ${ }^{66}$ In the climax, Laylā shows up at Sa'īd Nāṣir's house late one night, unhinged, screaming, "Come down here if you're a man!" 87 She insists that Sa'îd Nāṣir admit responsibility for her pathetic condition and for 'Alì's death, for the moral decay of the community and the corrosion of the nation. Here there is a marked difference between the ambivalence and restricted power of the mukhābarāt $\bar{\imath}$ in Brūfā, on the one hand, and the sadism and seemingly limitless authority exercised by Saî̀ Nāṣir. After the guard slaps her, Laylā spits in his face and he pistol-whips her in turn, throwing her to the ground before she skulks off into the night. Saiid Nāșir leaves the house with his driver Abū Maḥmūd shortly thereafter; cruising the city aimlessly, they listen to Qur’an recitation, sūrat Maryam (Mārī) to be

\footnotetext{
83 Ibid., 39 .

84 Ibid., 170-189.

85 Stefan Winter convincingly demonstrates how Arab nationalist historians and identitarian 'Alawī scholars writing during the early twentieth century contributed to a still widelyheld belief in an "Aleppo massacre" that took place in the midst of the Ottoman conquest of Greater Syria. "There is ultimately little to support the notion," Winter writes, "that the Mamluks' defeat at Marj Dabiq [in August 1516] gave way to a massacre of 'Alawis or other groups in Aleppo." Winter, A History of the 'Alawis, 77.

86 Yazbik, Lahā marāyā, 255 .

87 Ibid., 270.
} 
precise, which concerns how a barren woman may procreate through divine intervention, a reference to the Virgin Mary. Saīd Nāṣir can't get Laylă’s voice out of his head. ${ }^{88} \mathrm{He}$ still feels connected to her, tormented by conflicted feelings, unsure whether he "hated her deep in his soul" or "loved her so much he was afraid of getting near her." Saīd Nāșir is comforted, though, by one of his favorite maxims: "Punishment is one of the most important reasons for man's success, without punishment and fear there is no continuity." ${ }^{\prime 89}$ Here are two governing principles of regime doxa-punishment and fear. Sa'ìd Nāșir relishes the fact that Laylā will suffer further still. "She'll get her punishment," he grumbles, "she'll get her punishment...[even as] it crushed his heart." ${ }^{\prime \prime 0}$ If the novel started with a bang, it ends with a whimper: Laylā sobbing on the shoulder of an anonymous passenger as their bus crawls back towards the northwest coast, the 'Alawī heartland, a funereal return to her ancestral village where she will never truly feel at home.

Nabīl Sulaymān argues that Lahā marāyā is successful as a social commentary yet fails as a work of literature. ${ }^{91}$ By contrast, Muhammad Barrādah praises its rich characters and creative imagination. ${ }^{92}$ To the extent that a broken mirror still offers the possibility of reflection, and insofar as damaged subjects constituted through méconnaissance are still somehow implicated in a politics of (mis)recognition, there is no necessary contradiction in concluding that Lahā marāya turns on realist criticism of the regime and social surveillance as well as an imaginative recombination of history, memory, and myth in the service of a distinctive vision of politics and ('Alawī) identity in contemporary Syria.

\section{Seeing (and Listening) Like a State (Security Agent)}

Literary representations of uncivil society constitute an important yet underappreciated feature of late twentieth- and early twenty-first-century Syrian fiction. Whereas the individual and collective experience of incarceration or the inhuman application of torture against regime opponents animated Syrian

\footnotetext{
88 Ibid., 279-282.

89 Ibid., 286.

$90 \quad$ Ibid., $287-288$.

91 Nabīl Sulaymān, "Samar Yazbik tabḥath 'ammā warā' al-mirāh," Al-Hayāt, September 1, 2010.

92 Muhammad Barrādah, "Sijāl ḥawla riwāyat Samar Yazbik 'Lahā marāyā’: al-wāqi' al-sūrī bi-wijhihi al-usțūrī," Al-Hayāh, September 15, 2010.
} 
writing throughout the 1980 s and 1990s, state power in the Syrian mukhäbarāt novel of the 200os is depicted in terms of visual and auditory surveillance as well as other modes of affective domination. Brūfā and Lahā marāya illustrate some of the ways in which, as Peter Sloterdijk puts it, "the seeing of seeing becomes visible" 93 in Syrian literature, but also how, it might be added, following Sloterdijk, listening to listening becomes audible, and how both seeing and listening (indeed, affective experience as such) are essential to giving state power shape, making it comprehensible, perhaps even containable, within the space of the novel. ${ }^{94}$

It may be problematic to describe Syria as a "socialist society" senso stricto, but as with East German literature in the 1990s, Syrian writers in the 2000 s "no longer aspire[d] to change or improve (a no longer extant) socialist society, but rather [sought] to initiate a process of self-understanding, including a search for the author's own fragmented or injured identity and stance toward past and present events." ${ }^{95}$ Hasan and Yazbik imbue the mukhäbarāti and other individuals within the security apparatus in Bathist Syria with varying degrees of depth and complexity. Whereas Yazbik consistently calls attention to the ruthlessness of Sa'ìd Nāșir despite his familial and social connections to the victims of both state and intimate violence, Hasan winds up contextualizing the cruelty and callousness of the regime's minions in terms of their banal experiences and desires. Drawing upon a growing body of scholarship that situates representations of state power and surveillance in relation to political, social, and cultural practices, ${ }^{96}$ this article argues that the mukhābarāt novel, like George Orwell's Nineteen Eighty Four, offers a robust "case for comparative literary studies of surveillance representations." 97

93 Peter Sloterdijk, Critique of Cynical Reason, Trans. Michael Eldred (Minneapolis: University of Minnesota Press, 1987), 145 .

94 My thinking on the cultural politics of state power in Ba'thist Syria is deeply indebted to Lisa Wedeen, Ambiguities of Domination: Politics, Rhetoric, and Symbols in Contemporary Syria (Chicago: University of Chicago Press, 1999).

95 Jill E. Twark, Humor, Satire, and Identity: Eastern German Literature in the 19gos (Berlin: Walter de Gruyter, 2007), 75.

96 David Lyon, The Electronic Eye: The Rise of Surveillance Society (Minneapolis: University of Minneapolis Press, 1994); Idem. Surveillance Studies: An Overview. (Cambridge, UK: Polity, 2007); Zygmunt Bauman and David Lyon, Liquid Surveillance: A Conversation (Cambridge, U K: Polity Press, 2013).

97 Mike Nellis, "Since Nineteen Eighty Four: Representations of Surveillance in Literary Fiction," in New Directions in Surveillance and Privacy, eds. B. J. Goold, and Daniel Neyland (Cullompton, Devon: Willan Pub, 2009), 200 ffi. 
For Laylā in Lahā marāyā, the mirror is a site of reprieve, a vehicle to her own private heterotopia; Saīi Nāșir engages in what might be called informal or everyday forms of surveillance and social control over her. The fact that the listening booth—his very own portal to heterotopia—is where the mukhābarāti in $B r u \bar{f} \bar{a}$ both practices surveillance and hones his creative faculties suggests another space within what might be called the Syrian security archipelago, sites offering some semblance of mimetic coherence. State and non-state power- understood here as the politics and erotics of surveillance-are deployed in the text in order to achieve social control. But these texts also refigure the ambiguity and undecidability inherent to just existing in such dystopic circumstances as a means of destabilizing ideological conformity and the distinction between the state and its others. Both Hasan and Yazbik insist-each in her own way-that calling attention to the doubt and uncertainty that appears to represent the victory of authoritarian domination may also open up the possibility of undermining, or, at least challenging, those authoritarian raisons d'état. Moreover, these novels showcase the capabilities of literature to complicate and contest metanarratives of power promulgated by states and other coercive institutions (such as the family), to demonstrate their constructedness and their simultaneous durability, through moments of intimacy, vulnerability, and even humanity. The subtle insight made by Lisa Wedeen that certain transgressive acts-such as shining a light on the mechanics of authoritarian dictatorship through fiction- "are meaningful" without necessarily being "transformative" remains particularly resonant. ${ }^{98}$

"Syrian culture," Kahf wrote around the time Bashshār al-Asad was installed into power, "has become most associated with the posture of paranoia stemming from a realistic fear of a police state with a vast surveillance apparatus and great demands of public shows of allegiance." ${ }^{\prime 99}$ Syrians have long been intimidated, indeed terrorized, by the mukhäbarāt and a broader repressive apparatus. Fictionalized renditions of the mukhäbarāt - their characterization and caricature, one might say-can critically distance, objectify, and re-imagine the brutality of state power. But grinding war, mass death, physical destruction, and unprecedented human displacement make even those political concerns seem almost quaint by comparison.

Historians and Arabic literature scholars must continue to come to terms with what was at stake in political as well as literary terms from the outset of the uprising. Syrian novels from the 1990s and 200os narrativize and thereby

\footnotetext{
98 Lisa Wedeen, "Acting 'As If': Symbolic Politics and Social Control in Syria," Comparative Studies in Society and History Vol. 40, No. 3 (Jul., 1998), 523.

99 Kahf, "The Silences of Contemporary Syrian Literature," 232-233.
} 
interrogate the fear that many Syrians shed in rising up against authoritarian dictatorship. Consequently, Syrian literature from this period may represent the redemptive and productive — and, indeed, political — power of literature. One of the most consequential features of the mukhäbarāt novel, therefore, may be its capacity to showcase the power inherent to narration itself. 